\title{
Xanthine Oxidase and Lipid Peroxidation Inhibition of Taiwan Folkloric Medicine Factors Affecting Rhus semialata var. Roxburghiana Activities against Xanthine Oxidase and Ferrous Iron-induced Lipid Peroxidation on Mice Liver Mitochondria
}

\author{
Po-Wei Tsai ${ }^{1}$, Pei-Chin Lin², Ling-Ling Yang ${ }^{3,4}$, Ai-Ho Liao, ${ }^{5,6}$, Bo-Cheng Wang ${ }^{7, *}$, \\ Ming-Shun $\mathrm{Wu}^{8,9,10, *}$

\begin{abstract}
1Department of Medical Sciences Industry, College of Health Sciences, Chang Jung Christian University, Tainan, TAIWAN. 2Department of Clinical Pathology, Far Eastern Memorial Hospital, New Taipei, TAIWAN.

${ }^{3}$ School of Pharmacy, College of Pharmacy, Taipei Medical University, Taipei, TAIWAN.

${ }^{4}$ College of Acupuncture and Oriental Medicine, Houston, Texas, USA.

${ }^{5}$ Graduate Institute of Biomedical Engineering, National Taiwan University of Science and Technology, Taipei, TAIWAN.

${ }^{6}$ Department of Biomedical Engineering, National Defense Medical Center, Taipei, TAIWAN.

${ }^{7}$ Department of Chemistry, Tamkang University, New Taipei City, TAIWAN.

${ }^{8}$ Department of Internal Medicine, Wan Fang Hospital, Taipei Medical University, Taipei, TAIWAN.

${ }^{9}$ School of Medicine, College of Medicine, Taipei Medical University, Taipei, TAIWAN.

${ }^{10}$ School of Medicine Integrative Therapy Center for Gastroenterologic Cancers, Wan Fang Hospital, Taipei Medical University, Taipei, TAIWAN
\end{abstract}

\begin{abstract}
Background: Gout, a disease characterized by recurrent inflammatory for urate deposit from overactive xanthine oxidase, is common among Taiwanese. Rhus semialata var. roxburghiana (RSR) grows wildly in Central Mountain of Taiwan and used by aboriginal Taiwanese as traditional medicine for gout and hepatitis. Methods: In this study, the factors such as variations in RSR extracts in terms of geographical sources, aerial parts and extraction solvents were investigated for antioxidant capabilities, phytochemical analysis and inhibitory effects against xanthine oxidase and lipid peroxidation using ferrous ion as ROS inducer on mice liver mitochondria. Results: The results showed that ML- $n$-hexane and NS-acetone gave the maximum XO inhibitions $\left(\mathrm{IC}_{50}=16.74 \pm 0.74 \mu \mathrm{g} / \mathrm{mL}\right)$ and $\mathrm{LPO}$ inhibitions $\left(\mathrm{IC}_{50}=8.40 \pm 0.35 \mu \mathrm{g} / \mathrm{mL}\right)$ in the liver mitochondria of mice, respectively. And ML- $n$-hexane and NS-acetone contained phenolic and flavonoids compounds for its potential target components against XO and LPO in this study. Conclusion: Overall, RSR could lead to a medicinal potential as a suitable candidate for the development of a natural anti-gout and liver damage protective agent that have yet to be conducted.
\end{abstract}

Key words: Rhus semialata var. Roxburghiana extracts, Geographical source, Xanthine oxidase inhibitor, Free radical scavenging, Liver mitochondria LPO inhibitor.

\section{INTRODUCTION}

Gout is a disease characterized by recurrent inflammatory due to uric acid deposit in joint or tissue. ${ }^{1}$ An important enzyme of Xanthine oxidase $(\mathrm{XO})$ in the metabolism of hypoxanthine to xanthine and then to uric acid and produces reactive oxygen species (ROS), such as superoxide and hydrogen peroxide in biological systems $\mathrm{s}^{2,3}$ that normally forms chain reactions via lipid peroxidation, which have been proved to be the main cause for the oxidative damage and aging of the cells. Overactive $\mathrm{XO}$ leads to deposition of urate monohydrate in joints and tissues causing gout ${ }^{4,5}$ and some pathogen etic condition, such as vascular injury, inflammatory disease,
Submission Date: 12-06-2020; Revision Date: 25-08-2020; Accepted Date: 17-09-2020

DOI: 10.5530/ijper.54.4.201 Correspondence: Dr. Bo-Cheng Wang Department of Chemistry, Tamkang University, New Taipei City 251, TAIWAN.

Phone no: +886-0226215656 Email id: bcw@mail.tku. edu.tw Dr. Ming-Shun Wu School of Medicine, College of Medicine, Taipei Medical University, Taipei, TAIWAN. Phone no: +886-0227361661

Email id: vw1017@gmail. com

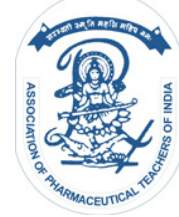

www.ijper.org 
chronic heart failure and ischemic injury related to ROS damage. ${ }^{6}$ Commercially available medicines for gout such as allopurinol-a well-known $\mathrm{XO}$ inhibitor, benzbromarone-a uricosuric drug, nonsteroidal antiinflammatory drugs (NSAIDs) and colchicine, have adverse side effects including liver necrosis due to allopurinol, ${ }^{7}$ and hepatotoxicity of benzbromarone, ${ }^{8}$ NSAIDs and colchicine. ${ }^{9,10}$ In this regard, continuous screening of potential natural source with antioxidant ability that balanced ROS to lessen lipid peroxidation of polyunsaturated fatty acids forming carcinogenic malondialdehyde (MDA) leading to cell injury or several pathological conditions. ${ }^{11,12}$

Taiwan is an island home to many kinds of native ethnobotany for folkloric medicine. Aboriginal Taiwanese such as Bunun tribe and Atayal tribe practice traditional medicine as treatment to some diseases using natural sources grown in their area. With the relatively high population of these aboriginal Taiwanese $(11.5 \%)$, many of their men suffers severe $(15.6 \%)$ hyperuricemia (serum level $>7 \mathrm{mg} / 100 \mathrm{~mL}$ ) making Taiwan one of the countries with high gout population in the world (prevalence: $0.16-0.67 \%)^{13}$

Rhus semialata var. roxburgbiana (RSR) (Anacardiaceae) is wildly grown in Taiwan Central Mountain from thickets and secondary forests at low altitudes in middle and north of Taiwan. ${ }^{14}$ This plant has been reported to remedy diseases such as gout and hepatitis with high potential antioxidant and polypheno $1^{15}$ as well as pharmacological activities including anti-diarrheal activity, ${ }^{16}$ antithrombin capability, ${ }^{17}$ pBR322 DNA plasmid breaking ability and anti-tobacco mosiac virus. ${ }^{18,19}$ On the other hand, The secondary metabolites or crude extract have been found from RSR such as phenolics, flavonoids and hydrolysable tannins etc. These compounds or crude extracts also have inhibited antioxidant, antimicrobial and antiviral activities etc. Overall, we summarize in Table 1 that the Biological and pharmacological properties of compounds or crude extracts from RSR. ${ }^{20}$

RSR has been used for a long time as folkloric medicine, albeit scientific studies proving its efficacy to some diseases are limited. This study aimed to investigate the factors such as variations in geographical source (Middle and Northern Taiwan), aerial parts (stem, branch and leaf) and extraction solvents ( $n$-hexane, ethyl acetate (EA), acetone, 95\% ethanol and water) in relation to its antioxidant capabilities via radical scavenging abilities of DPPH, hydrogen peroxide, superoxide anion, ferrous ion chelating capability and ferric reducing antioxidant power (FRAP); phytochemical analysis via total phenolic, flavonoid and flavanol contents; and inhibitory effects against xanthine oxidase $(\mathrm{XO})$ and lipid peroxidation
(LPO) using ferrous ion as ROS inducer on mice liver mitochondria. An insight on the effect of these factors to RSR capabilities could lead to a medicinal potential of this specie as suitable candidate for the development of a natural anti-gout and liver damage protective agent that have yet to be conducted.

\section{MATERIALS AND METHODS}

\section{Chemicals and reagents}

All reagents were of analytical grade. Catalase, horseradish peroxidase, xanthine oxidase were obtained from Calzyme laboratories Inc. Acetic acid was obtained from Kanto chemical Co., INC. Potassium phosphate $\left(\mathrm{KH}_{2} \mathrm{PO}_{4}\right)$, sodium hydroxide $(\mathrm{NaOH})$ and sodium phosphate $\left(\mathrm{Na}_{2} \mathrm{HPO}_{4}, \mathrm{NaH}_{2} \mathrm{PO}_{4}\right)$ were obtained from J.T. Baker. Ferric chloride 6-hydrate $\left(\mathrm{FeCl}_{3} \cdot 6 \mathrm{H}_{2} \mathrm{O}\right)$ was obtained from Panreac. Hydrogen peroxide $\left(\mathrm{H}_{2} \mathrm{O}_{2}\right)$ was obtained from Fluka. DPPH (2,2-diphenyl-1picrylhydrazyl), 4-dimethylaminocinnamaldehyde (DMACA), allopurinol, aluminium chloride $\left(\mathrm{AlCl}_{3}\right)$, bovine serum albumin, dimethyl sulfoxide (DMSO), ethylene dinitrilotetraacetic acid (EDTA), epicatechin, ferrous chloride $\left(\mathrm{FeCl}_{2}\right)$, ferrozine, Folin-Ciocalteu's phenol reagent, gallic acid, methanol, phenazine methosulfate (PMS), nitro blue tetrazolium (NBT), , phenol red solution, rutin, superoxide dismutase (SOD), sodium acetate, 1,1,3,3-tetraethoxypropane (TEP), trolox, 2,4,6-tripyridyl-s-triazine (TPTZ), trifluoroacetic acid, 2-thiobarbi-turic acid (TBA), reduced form $(\beta-\mathrm{NADH})$, xanthine and $\beta$-nicotinamide adenine dinucleotide were obtained from Sigma (St. Louis, MO).

\section{Animals}

ICR mice were obtained from BioLASCO Taiwan Co., Ltd. In accordance with the Laboratory Animal Ethics Committee of Taipei Medical University, the rats are used for this study was cared. In plastic cages mice were housed in the maintained temperature and with food and water, the animal house environment was kept on a 12-h light/12-h dark cycle. The experiments were conducted in accordance with the guidelines of the Experimental Animal Center of Taipei Medical University and the Chinese Society of Experimental Animal Science in Taiwan and the guidelines for the care and use of experimental animals were approved.

\section{Extraction of plant and preparation of tested solution}

RSR fresh stems, branches and leaves were harvested from Nantou County and Wulai District, New Taipei City 


\section{Table 1: Biological and pharmacological properties of compounds or crude extracts from RSR. ${ }^{20}$}

\begin{tabular}{|c|c|c|c|}
\hline Plant parts & Contents & Compound/ type of extract & $\begin{array}{c}\text { Biological and } \\
\text { Pharmacological properties }\end{array}$ \\
\hline Leaves & \multirow{3}{*}{$\begin{array}{c}\text { Protocatechuic acid, } \\
\text { p-coumaric acid, gallic acid, } \\
\text { catechin, quercetin, methyl gallate, } \\
\text { hydroxydammarenone, } \\
\text { semialactone, moronic acid and } \\
\text { betulonic acid }\end{array}$} & $\begin{array}{l}\text { Gallic acid and methyl gallate/ ethanol } \\
\text { and aqueous extracts }\end{array}$ & Antibacterial and antimicrobial \\
\hline Stem & & $\begin{array}{l}\text { Hydroxydammar-enone, moronic and } \\
\text { betulonic acid/ petroleum ether extract }\end{array}$ & Anticholesterol and antiviral \\
\hline Branches & & Semialactone & Anticholesterol \\
\hline Fruits & Gallic acid, tannic acid and flavanoids & Methanol extract & Antidiarrhoeal \\
\hline Gall & Gallotannins and gallic acid & $\begin{array}{c}\text { Gallotannins and gallic acid /Ether, } \\
\text { EtOAc, ethanol, methanol and aqueous } \\
\text { extracts }\end{array}$ & $\begin{array}{c}\text { Anticaries, antibacterial, } \\
\text { antioxidant, anticholesterol and } \\
\text { antidiabetic }\end{array}$ \\
\hline
\end{tabular}

in Taiwan (middle and northern Taiwan, respectively). Each voucher specimen were prepared and stocked at Department of Pharmacognosy, Taipei Medical University. Samples were cleaned and washed, then dried in the oven at $40^{\circ} \mathrm{C}$ for two days. Each dried sample of RSR $(100 \mathrm{~g})$ with the ratio 1:10 (Plant sample: fold solvents ( $n$-hexane, EA, acetone, 95\% ethanol and water)) was refluxed and extracted for twice. The combined crude extracts from each solvent were filtered, concentrated in vacuo (Eyela CCA1111), then dried using lyophilizer (Eyela FDU-1200) and determined the percentage recovery. Each crude extract $(20 \mathrm{mg}$ ) was dissolve in $1 \mathrm{~mL}$ DMSO as a stock solution and procedure is following the assays where the tested solution with PBS, methanol or distilled water (concentration of DMSO $<0.05 \%$ ) is serially dilution method.

\section{XO inhibitory capability of RSR extract}

$\mathrm{XO}$ activity assay was performed according to Umamaheswari and Unno method with some modification. Briefly, each RSR extract was prepared at a series concentration where $50 \mu \mathrm{L}$ of the tested solution was mixed with $35 \mu \mathrm{L}$ of $1 \mathrm{X}$ PBS and solution containing $\mathrm{XO}(40 \mu \mathrm{L}, 0.5 \mathrm{U} / \mathrm{mL})$. After incubating at room temperature for $15 \mathrm{~min}, 50 \mu \mathrm{L}$ of xanthine solution $(100 \mu \mathrm{M})$ was added following to incubation for $30 \mathrm{~min}$ at room temperature before hydrogen chloride $(25 \mu \mathrm{L}, 1 \mathrm{~N})$ was added and mixed well. $295 \mathrm{~nm}$ absorbance was measured using ELISA reader (Synergy $\mathrm{H} 4$ Hybrid Reader). The DD- $\mathrm{H}_{2} \mathrm{O}$ is blank group and the control group contains all reagents without the sample. Allopurinol was used as the positive control agent of XO inhibitor. ${ }^{4,21}$ The XO inhibitory effect of each extract was calculated according to the following formula

$$
\text { Percent Inhibition }=\frac{\left(A_{\text {control }}-A_{\text {sample }}\right)}{\left(A_{\text {control }}-A_{\text {blank }}\right)} \times 100
$$

Each tested extract $\mathrm{IC}_{50}$ values was calculated by linear regression analysis.

\section{Inhibitory capability of LPO on mice liver mitochondria}

\section{Preparation of mice liver mitochondria and protein content quantitation}

The ICR mice (about 4 to 6 weeks) were sacrificed by carbon dioxide and the livers were removed immediately to perfuse with $0.1 \mathrm{M}, \mathrm{pH} 7.4$ ice-cold PBS and homogenized using the homogenizer (Wheaton, Millville, NJ, USA). The homogenate is suspend in PBS, then centrifuged using $2000 \mathrm{rpm}$ at $4^{\circ} \mathrm{C}$ for 10 min to separate. After re-centrifuge using $13000 \mathrm{rpm}$ for $10 \mathrm{~min}$ at $4^{\circ} \mathrm{C}$, The clear suspensions were finished to obtain mitochondrial fraction. Pipette mitochondrial suspensions of different concentrations into an eppendorf $1.5 \mathrm{~mL}$ volume and adjust the volume to $50 \mu \mathrm{L}$ with PBS before adding the protein reagent and mixing with the vortex mixer. Absorbance was measured at $595 \mathrm{~nm}$ and a standard curve was generated from a plot of bovine serum albumin and the corresponding absorbance is used for protein in the mitochondrial solution quantitatively determination.

\section{Inhibitory capability of each RSR extract on ferrous chloride induced LPO production in mice liver mitochondria}

The LPO inhibitory activity was determined quantitatively by thiobarbituric acid reactive substances (TBARS) assay. A $500 \mu \mathrm{L}$ reaction mixture solution (liver mitochondria $100 \mu \mathrm{L}$, PBS buffer $200 \mu \mathrm{L}, \mathrm{FeCl}_{2}$ solution $(4 \mathrm{mM}) 100 \mu \mathrm{L}$ and $100 \mu \mathrm{L}$ of each extract or reference standard (trolox)) was incubated at $37^{\circ} \mathrm{C}$ for $1 \mathrm{hr}$ and then centrifuged at $4000 \mathrm{rpm}$ for $10 \mathrm{~min}$. The reaction was added with $\mathrm{H}_{3} \mathrm{PO}_{4} 375 \mu \mathrm{L}$, DD-water $200 \mu \mathrm{L}$ and TBA $125 \mu \mathrm{L}$, then incubated at $90^{\circ} \mathrm{C}$ for $66 \mathrm{~min}$. The termination of the reaction is following the addition of methanol- $\mathrm{NaOH}$ (the ratio $9.1: 0.9 \mathrm{v} / \mathrm{v}$ ) $350 \mu \mathrm{L}$. MDA $(\mathrm{TBA})_{2}$ product $532 \mathrm{~nm}$ absorbance of formed was quantitatively measured against as a blank (DD $\mathrm{H}_{2} \mathrm{O}$ only) and control (all reagents without the 
sample). Data were recorded where LPO inhibition was calculated as mentioned earlier and each extract $\mathrm{IC}_{50}$ values were calculated by linear regression analysis.

\section{LPO production of each RSR extract on mice liver mitochondria}

A separate experiment for LPO production was measured using at least 2 or 3 times the concentration of $\mathrm{IC}_{50}$ values previously determined from ferrous chloride induced LPO inhibitory effect of the extracts where the same preparation without $\mathrm{FeCl}_{2}$ addition and quantitative MDA (TBA) ${ }_{2}$ product measurements were performed.

\section{Antioxidant capability determination}

Determination of antioxidant capabilities of each RSR extracts was evaluated using the previous method. ${ }^{15}$

\section{DPPH free radical-scavenging capability}

The DPPH radical scavenging activity of the extracts was performed where $100 \mu \mathrm{L}$ of different concentration of each RSR extract solutions in methanol and $50 \mathrm{mM}$ DPPH $100 \mu \mathrm{L}$ of solution in methanol were mixed, shaken and incubated in the dark at room temperature for $30 \mathrm{~min}$. Absorbance measurements were carried out at $517 \mathrm{~nm}$ and methanol with DPPH solution as the standard and blank, respectively. The reaction mixture solution has lower absorbance, which indicated higher free radical-scavenging activity. Use the following formula to calculate the ability to scavenge DPPH free radicals

$$
\text { Percentage scavenging }=\left(1-\frac{\text { Asample }}{\text { Acontrol }}\right) \times 100
$$

And each extract $\mathrm{IC}_{50}$ values are calculated by linear regression analysis.

\section{Superoxide anion radical ( $\left.\mathrm{O} 2^{\circ}-\right)$-scavenging capability}

Generation of $\mathrm{O}_{2}^{--}$was done by dissolving $\mathrm{O}_{2}$ which is ability to reduce NBT to purple formazan was measured in PMS-NADH coupling in a non-enzymatic system. Briefly, Add $936 \mu \mathrm{M} \beta$-NADH $250 \mu \mathrm{L}$ and $300 \mu \mathrm{M}$ NBT equal volume with $100 \mu \mathrm{L}$ of a solution containing a series of concentrations $(\mu \mathrm{g} / \mathrm{mL})$ of extract. The reaction is added $120 \mu \mathrm{M}$ PMS $250 \mu \mathrm{L}$ to the mixture, then incubated at $37^{\circ} \mathrm{C}$ for $5 \mathrm{~min}$. Absorbance at 560 $\mathrm{nm}$ was measured by control group that contains all the reagent where the amount of solution extracts was replaced with the same amount of $\mathrm{DD} \mathrm{H}_{2} \mathrm{O}$ and SOD (super oxidase) is the reference standard. Dissolve all the above reagents in freshly prepared in sodium phosphate buffer ( $\mathrm{pH}$ 7.4). The superoxide anion radical $\left(\mathrm{O}_{2}^{--}\right)$-scavenging activity $(\%)$ was calculated as mentioned earlier and each extract $\mathrm{IC}_{50}$ values are calculated by linear regression analysis.

\section{Hydrogen peroxide scavenging capability}

Hydrogen peroxide scavenging ability of the RSR extracts were measured using $500 \mu \mathrm{L}$ reaction mixture containing different concentration of each RSR extract solutions in methanol and $200 \mu \mathrm{L}$ of $4 \mathrm{mM} \mathrm{H}_{2} \mathrm{O}_{2}$ solution, incubated at room temperature for $20 \mathrm{~min}$ followed by the addition of $300 \mu \mathrm{L}$ red solution (phenol red $7.5 \mathrm{mM}$ in $200 \mathrm{mM}$, HRPase $500 \mu \mathrm{g} / \mathrm{mL}$ and potassium phosphate buffer in $\mathrm{pH}$ 6.2). After another $10 \mathrm{~min}$, then incubated at room temperature in an ice bath for 10 min to terminate the reaction afterwards its $610 \mathrm{~nm}$ absorbance was measured using ELISA reader. Catalase, $700 \mu \mathrm{L}$ of $\mathrm{ddH}_{2} \mathrm{O}$ with HRPase-phenol red solution $(300 \mu \mathrm{L})$ and $500 \mu \mathrm{L}$ of $\mathrm{dd}_{2} \mathrm{O}$ with $4 \mathrm{mM}$ $\mathrm{H}_{2} \mathrm{O}_{2}(200 \mu \mathrm{L})$ and HRPase-phenol red solution (300 $\mu \mathrm{L}$ ) were used as reference standard, blank and control group, respectively. The scavenging effect was calculated as mentioned earlier and each extract $\mathrm{IC}_{50}$ values are calculated by linear regression analysis.

\section{Ferrous ion chelating capability}

The each RSR extract ferrous ion chelating ability was monitored by $562 \mathrm{~nm}$ absorbance of the formed ferrous ion-ferrocene complex. The total volume of the reaction mixture containing each RSR extract or standard compound (EDTA), $\mathrm{FeCl}_{2}(2 \mathrm{mM})$ and tetrahydrofuran ( $5 \mathrm{mM})$ was adjusted to $1 \mathrm{~mL}$ with methanol and then incubated at room temperature for $10 \mathrm{~min}$. Lower absorbance indicates higher metal chelation activity. The ability of each RSR extract to chelate ferrous ions is expressed as

Percent Chelating ability $=\left(1-\frac{\text { Asample }(562 \mathrm{~nm})}{\text { Acontrol }(562 \mathrm{~nm})}\right) \times 100$

\section{Ferric reducing antioxidant power (FRAP)}

FRAP reagent was prepared by mixing $300 \mathrm{mM}$ acetate buffer (pH 3.6), $5 \mathrm{mM}$ methanol TPTZ and $20 \mathrm{mM}$ ferric chloride $\left(\mathrm{FeCl}_{3}\right)(10: 1: 1, \mathrm{v} / \mathrm{v} / \mathrm{v})$. Twenty-five microliter $(25 \mu \mathrm{L})$ of extract solution (final concentration: $100 \mu \mathrm{g}$ / $\mathrm{mL}$ ) was mixed with $725 \mu \mathrm{L}$ of the FRAP reagent for 4 min and absorbance was measured at $593 \mathrm{~nm}$. Results were expressed as the trolox equivalent capacity values $(\mu \mathrm{M})$.

\section{Phytochemical analysis}

\section{Total phenolic content (TPC)}

TPC of the extracts was estimated using FolinCiocalteu's reagent (10x diluted with DD water). Briefly, Folin-Ciocalteu's $500 \mu \mathrm{L}$ was added to each extract $100 \mu \mathrm{L}$ solution. After $30 \mathrm{sec}, 7.5 \% \mathrm{Na}_{2} \mathrm{CO}_{3} 400 \mu \mathrm{L}$ 
was added and then incubated at $50^{\circ} \mathrm{C}$ for $30 \mathrm{~min}$. Absorbance was measured at $765 \mathrm{~nm}$ against a blank. Gallic acid was used as reference standard.

\section{Total flavonoid content}

Total flavonoid content was estimated using aluminum chloride colorimetric method. Briefly, $500 \mu \mathrm{L}$ of each RSR extract solutions were mixed with same volume $2 \%$ aluminum chloride (ratio 1:1) and then incubated at room temperature for $1 \mathrm{hr}$. The $430 \mathrm{~nm}$ absorbance was measured against a blank and rutin was used as a reference standard.

\section{Total flavanol content}

Each RSR extract solutions were mixed with the 4-dimethylaminocinnamaldehyde (DMACA). Absorbance was measured at $640 \mathrm{~nm}$ against a blank and epicatechin was used as a reference standard.

\section{Statistical analysis}

Data were presented as mean \pm SD. All experiments were performed for triplicate. General linear model (Univariate) and Tukey's HSD post-hoc tests were applied to determine the influence of factors such as geographical source, aerial parts and extraction solvents used. The correlation is analysed by Pearson correlation where $p<0.05$ was regarded as significantly different from the control group.

\section{RESULTS}

\section{The percentage recovery of RSR extracts}

Phytochemical constituents recovered in RSR depend on the nature of extracting solvents used. Solvents with different polarities ( $n$-hexane, ethyl acetate, acetone, $95 \%$ ethanol, water) were used and such variations affect the percentage recovery as well as bioactivities of the extracts due to complex structure and nature of these phytoconstituents. According to Table 1, RSR methanol and aqueous extracts showed that it contained phenolic compounds. The results of Table 2 showed that the ML ethanol and aqueous after $n$-hexane extract have larger yield more than other parts extracts. And non-polar $n$-hexane extract showed the poor extraction yield.

\section{XO inhibition, LPO production and LPO inhibitory capability}

Xanthine oxidase $(\mathrm{XO})$ is plays the important role in human purine nucleotide metabolism. Its main role is to catalyze the oxidation of hypoxanthine to xanthine and xanthine to uric acid. ${ }^{22}$ Over production and/or under excretion of XO caused ROS production and increased uric acid generation leading to hyperuricemia such as

\begin{tabular}{|c|c|c|c|c|c|}
\hline \multicolumn{5}{|c|}{ Table 2: The yield (\%) of each RSR extract. } \\
\hline \multirow{2}{*}{ RSR $^{* a}$ tb } \\
\cline { 2 - 6 } & \multicolumn{7}{|c|}{-hexane } & EA & Acetone & Ethanol & Water \\
\hline MS & 0.70 & 1.24 & 1.66 & 0.14 & 3.77 \\
\hline MB & 1.90 & 5.45 & 9.10 & 9.90 & 12.70 \\
\hline ML & 4.95 & 9.53 & 6.40 & 16.40 & 21.80 \\
\hline NS & 0.63 & 1.94 & 1.10 & 2.84 & 2.33 \\
\hline NB & 0.90 & 3.00 & 2.25 & 7.73 & 9.40 \\
\hline NL & 3.60 & 8.54 & 6.87 & 16.62 & 18.20 \\
\hline
\end{tabular}

${ }^{\text {"a }}$ Geographical source and aerial part-

M: Middle Taiwan; N: Northern Taiwan

S: Stem; B: Branch; L: Leaf

"b. The yield was calculated by the extract weight/dried material (RSR) weight $\times 100 \%$

gout. Treatment for gout patient includes XO inhibitor that blocks the production of uric acid. Allopurinol, benzbromarone, NSADS and colchicine are commonly used but have been reported with adverse side effects like hepatotoxicity that relates to LPO production since it can be damaged liver tissues to pathological conditions.

In this study, the capability of RSR extracts to inhibit $\mathrm{XO}$ and LPO production were determined. Based on the results of Table 3 showed that ML- $n$-hexane, MS- $n$ hexane, NS-ethanol extracts are more potential to develop as XO inhibitor $\left(\mathrm{IC}_{50}: 16.74 \pm 0.74,26.53 \pm 0.54\right.$ and $26.80 \pm 0.39 \mu \mathrm{g} / \mathrm{mL}$, respectively), in comparison to the positive control (allopurinol) $\left(\mathrm{IC}_{50}: 0.57 \pm 0.02 \mu \mathrm{g} /\right.$ $\mathrm{mL}$ ). On the other hand, NS-acetone, NL-water and NL-EA extract exerted the potential inhibitory effects on ferrous ion-induced $\mathrm{LPO}\left(\mathrm{IC}_{50}: 8.40 \pm 0.35,9.42 \pm 1.11\right.$, $10.43 \pm 0.46 \mu \mathrm{g} / \mathrm{mL}$, respectively) as compared to positive control (trolox) ( $\mathrm{IC}_{50}: 9.21 \pm 0.32 \mu \mathrm{g} / \mathrm{mL}$ ). All extracts tested did not induced LPO production even with the concentration of over double doses of $\mathrm{IC}_{50}$ was applied. Discussion of potential phytochemical of RSR ML- $n$-hexane, MS- $n$-hexane and NS-ethanol, leaves and stem extracts may contained phenolic components as its target compound to be the XO inhibitor and showed the inhibitory effect on iron-induced LPO. ${ }^{20}$

\section{Antioxidant capabilities and phytochemical analysis}

An imbalance between ROS and antioxidant enzyme in the body will react with protein, membrane and DNA. Toxic LPO products, carcinogenic MDA, ${ }^{23}$ and $\mathrm{XO}$ production contributed to ROS production. Recently, the antioxidant treatment has been seriously considered as an effective strategy because antioxidants can decrease LPO reaction and scavenge free radical to counteraction the ROS damage. ${ }^{24}$ Therefore, in this study, antioxidant capabilities and phytochemical analysis of RSR were evaluated. All antioxidant capabilities and phytochemical 


\begin{tabular}{|c|c|c|c|}
\hline $\mathbf{R S R}^{* a}$ & $\begin{array}{l}\text { Extract } \\
\text { solvent }\end{array}$ & $\begin{array}{c}\text { Xanthine } \\
\text { oxidase }\end{array}$ & LPO \\
\hline \multirow{5}{*}{ MS } & $n$-hexane & $26.53 \pm 0.54$ & $55.24 \pm 0.63$ \\
\hline & EA & $43.87 \pm 0.11$ & $10.78 \pm 0.74$ \\
\hline & Acetone & $85.45 \pm 2.91$ & $13.17 \pm 1.11$ \\
\hline & Ethanol & $148.10 \pm 0.38$ & $30.26 \pm 0.36$ \\
\hline & Water & $119.44 \pm 9.83$ & $21.34 \pm 0.29$ \\
\hline \multirow{5}{*}{ MB } & $n$-hexane & $>300$ & $29.67 \pm 1.77$ \\
\hline & $E A$ & $>300$ & $51.32 \pm 2.34$ \\
\hline & Acetone & $190.14 \pm 1.84$ & $88.98 \pm 7.42$ \\
\hline & Ethanol & $78.81 \pm 1.51$ & $66.27 \pm 2.03$ \\
\hline & Water & $>500$ & $40.52 \pm 1.43$ \\
\hline \multirow{5}{*}{ ML } & $n$-hexane & $16.74 \pm 0.74$ & $72.92 \pm 2.57$ \\
\hline & EA & $>300$ & $13.52 \pm 3.19$ \\
\hline & Acetone & $>300$ & $28.68 \pm 0.76$ \\
\hline & Ethanol & $>300$ & $23.94 \pm 0.86$ \\
\hline & Water & $>300$ & $14.52 \pm 0.48$ \\
\hline \multirow{5}{*}{ NS } & $n$-hexane & $>300$ & $19.41 \pm 1.23$ \\
\hline & EA & $66.72 \pm 7.40$ & $21.36 \pm 1.68$ \\
\hline & Acetone & $38.18 \pm 2.71$ & $8.40 \pm 0.35$ \\
\hline & Ethanol & $26.80 \pm 0.39$ & $25.86 \pm 0.30$ \\
\hline & Water & $101.69 \pm 13.60$ & $31.83 \pm 0.71$ \\
\hline \multirow{5}{*}{ NB } & $n$-hexane & $129.31 \pm 2.32$ & $48.36 \pm 2.30$ \\
\hline & EA & $76.31 \pm 5.94$ & $40.16 \pm 1.08$ \\
\hline & Acetone & $177.31 \pm 7.72$ & $22.66 \pm 1.88$ \\
\hline & Ethanol & $72.20 \pm 0.47$ & $43.35 \pm 3.12$ \\
\hline & Water & $74.35 \pm 2.73$ & $54.72 \pm 3.37$ \\
\hline \multirow{5}{*}{ NL } & $n$-hexane & $>120$ & $43.36 \pm 1.50$ \\
\hline & EA & $>200$ & $10.43 \pm 0.46$ \\
\hline & Acetone & $128.62 \pm 3.16$ & $37.22 \pm 0.45$ \\
\hline & Ethanol & $>300$ & $22.35 \pm 0.89$ \\
\hline & Water & $>300$ & $9.42 \pm 1.11$ \\
\hline $\begin{array}{l}\text { Positive } \\
\text { control }\end{array}$ & - & $\begin{array}{c}\text { (Allopurinol) } \\
0.57 \pm 0.02\end{array}$ & $\begin{array}{c}\text { (Trolox) } \\
2.52 \pm 0.37\end{array}$ \\
\hline
\end{tabular}

${ }^{{ }^{* a}}$ Geographical source and aerial part-

M: Middle Taiwan; N: Northern Taiwan

S: Stem; B: Branch; L: Leaf

analysis of each RSR extract were shown in Table 4 and Table 5, respectively. Results showed that MS-EA extract gave the highest superoxide anion radical scavenging $\left(\mathrm{IC}_{50}: 53.48 \pm 0.75 \mu \mathrm{g} / \mathrm{mL}\right.$ ), FRAP (equivalent trolox $116.40 \pm 0.34 \mu \mathrm{M})$ and $\mathrm{DPPH}$ scavenging activity $\left(\mathrm{IC}_{50}\right.$ : $1.53 \pm 0.08 \mu \mathrm{g} / \mathrm{mL}$ ) while the best hydrogen peroxidescavenging capability was observed in MS-acetone extract. Additionally, phytochemical analysis showed that higher total phenolic content was in MS, especially in MS acetone and EA extracts (455.17 \pm 9.29 and 425.64 \pm 6.09 $\mu \mathrm{g}$ Gallic acid/mg), higher total flavonoid (ML-EA extract: $73.24 \pm 5.04 \mu \mathrm{g}$ Rutin/mg) and flavanol (NLEA extract: $110.65 \pm 7.48 \mu \mathrm{g}$ epicatechin $/ \mathrm{mg}$ ) contents were mainly in leaf extracts. Phenolic compounds have been found from RSR stem extract. ${ }^{20}$ The phenolic compounds have been showed various biological activities. The literature also showed that ferulic acid and gallic acid related phenolic compounds were found against $\mathrm{XO}$ and COX-2 for anti-inflammatory activity. ${ }^{25}$

\section{DISCUSSION}

\section{Correlation between XO and LPO inhibition, antioxidant capabilities and phytochemical contents}

Cell damages due to ROS are related to LPO productions and the antioxidant capabilities of plant extract that can inhibit the LPO production could lead to overall protection against cell damages, aging and necrosis. In this study, LPO inhibition with DPPH radical scavenging $(r=0.507$, $p=0.004)$ and FRAP $(r=0.521, p=0.003)$ was median relation and showed a relationship with polyphenol content $(r=0.496, p=0.005)$, flavonoid content $(r=$ $0.461, p=0.010)$ and flavanol content $(r=0.421$, $p=0.040)$. These possibly explain that the antioxidant and radical scavenging ability of the extract are effective strategy for liver protection where ROS is involved in the main mechanisms of liver injury. Furthermore, FRAP exerted high correlation with DPPH scavenging capability $(r=0.702, p<0.001)$ and total phenolic content $(r=0.833, p<0.001)$ suggesting a strong relationship of phenolic compounds present in the extract with its antioxidant activities. The flavonoid content with flavanol content showed high linear correlation $(r=$ $0.838, p<0.001)$ and RSR leaf polar extracts with higher flavonoid and flavanol content which possibly suggest that flavonoids and flavanols are largely distributed in the highly exposed plant part to sunlight due to its high-sunlight response. ${ }^{26}$ The $\mathrm{XO}$ inhibitory effect showed low correlation with other activities and nonpolar extracts exerted higher XO inhibition, albeit some reports found out that phytochemical constituent of some plant extracts in solvents with lower polarity than water exhibit significant $\mathrm{XO}$ inhibitions as compared to standard. $22,27,28$

The influence of geographical sources, aerial parts and extraction solvents on the XO and LPO inhibitory capabilities, antioxidant capabilities and RSR extracts phytochemical content analysis

The factor influence that is including variations in geographical source, aerial parts and extraction solvents of RSR extracts, except the hydrogen peroxide scavenging activity was summarized (Figure 1). The solvents polarities play a main factor in DPPH (water, EA and ethanol extracts) and superoxide anion (acetone and water extracts) scavenging capabilities, XO inhibitory effects ( $n$-hexane and EA extracts) and FRAP (water extract) since it relate to the nature of extracts in terms 


\begin{tabular}{|c|c|c|c|c|c|c|}
\hline \multirow{2}{*}{$\mathbf{R S R}^{* a}$} & \multirow{2}{*}{ Extract solvent } & DPPH & $\begin{array}{l}\text { Hydrogen } \\
\text { peroxide }\end{array}$ & $\begin{array}{l}\text { Superoxide } \\
\text { anion }\end{array}$ & \multirow{2}{*}{$\begin{array}{c}\mathrm{Fe}^{2+} \text { chelating } \\
\text { capability }\end{array}$} & \multirow{2}{*}{$\begin{array}{c}\text { FRAP } \\
\begin{array}{c}\text { Equiv. trolox } \\
(\mu \mathrm{M})^{* b}\end{array}\end{array}$} \\
\hline & & \multicolumn{3}{|c|}{$\mathrm{IC}_{50}(\mu \mathrm{g} / \mathrm{mL})$} & & \\
\hline \multirow{5}{*}{ MS } & n-hexane & $56.25 \pm 1.13$ & $>300$ & $226.56 \pm 2.07$ & 0 & $6.00 \pm 0.14$ \\
\hline & EA & $1.53 \pm 0.08$ & $264.25 \pm 4.75$ & $53.48 \pm 0.75$ & 0 & $116.40 \pm 0.34$ \\
\hline & Acetone & $1.65 \pm 0.16$ & $208.03 \pm 1.87$ & $63.47 \pm 2.94$ & 0 & $114.81 \pm 0.59$ \\
\hline & Ethanol & $8.03 \pm 0.62$ & $>300$ & $80.89 \pm 2.93$ & 0 & $56.40 \pm 0.40$ \\
\hline & Water & $5.85 \pm 0.26$ & $>300$ & $58.48 \pm 2.45$ & $9.20 \pm 2.43$ & $110.52 \pm 1.34$ \\
\hline \multirow{5}{*}{ MB } & $n$-hexane & $109.12 \pm 17.67$ & $>300$ & $141.09 \pm 3.49$ & 0 & $3.68 \pm 0.09$ \\
\hline & EA & $23.21 \pm 5.39$ & $>300$ & $>100$ & 0 & $17.41 \pm 0.39$ \\
\hline & Acetone & $78.68 \pm 5.38$ & $>300$ & $>100$ & 0 & $7.37 \pm 0.14$ \\
\hline & Ethanol & $24.04 \pm 0.60$ & $>300$ & $>100$ & 0 & $30.67 \pm 0.28$ \\
\hline & Water & $6.86 \pm 0.78$ & $>300$ & $199.52 \pm 4.28$ & 0 & $53.74 \pm 0.41$ \\
\hline \multirow{5}{*}{ ML } & n-hexane & $113.46 \pm 6.56$ & $>300$ & $>100$ & 0 & $7.11 \pm 0.09$ \\
\hline & EA & $17.26 \pm 0.85$ & $>300$ & $144.53 \pm 2.00$ & $4.92 \pm 0.92$ & $66.26 \pm 1.34$ \\
\hline & Acetone & $12.97 \pm 0.66$ & $>300$ & $>100$ & 0 & $35.62 \pm 0.61$ \\
\hline & Ethanol & $13.32 \pm 0.89$ & $>300$ & $>100$ & $0.78 \pm 0.19$ & $61.94 \pm 1.03$ \\
\hline & Water & $5.15 \pm 0.41$ & $504.47 \pm 3.70$ & $53.79 \pm 0.31$ & 0 & $110.74 \pm 0.25$ \\
\hline \multirow{5}{*}{ NS } & n-hexane & $46.75 \pm 2.73$ & $>300$ & $>100$ & 0 & $9.69 \pm 0.09$ \\
\hline & EA & $12.60 \pm 0.59$ & $>300$ & $>100$ & 0 & $29.29 \pm 0.17$ \\
\hline & Acetone & $22.87 \pm 1.61$ & $>300$ & $>100$ & 0 & $26.25 \pm 0.01$ \\
\hline & Ethanol & $7.82 \pm 0.31$ & $>300$ & $>100$ & 0 & $46.56 \pm 0.42$ \\
\hline & Water & $7.75 \pm 0.42$ & $>300$ & $107.20 \pm 0.26$ & $5.96 \pm 0.74$ & $75.93 \pm 0.30$ \\
\hline \multirow{5}{*}{ NB } & n-hexane & $135.53 \pm 2.90$ & $>300$ & $>100$ & 0 & $5.29 \pm 0.05$ \\
\hline & EA & $15.19 \pm 0.83$ & $>300$ & $223.29 \pm 1.95$ & 0 & $42.35 \pm 0.77$ \\
\hline & Acetone & $51.04 \pm 3.05$ & $>300$ & $>100$ & 0 & $15.58 \pm 0.16$ \\
\hline & Ethanol & $23.76 \pm 0.05$ & $>300$ & $>100$ & 0 & $41.97 \pm 0.15$ \\
\hline & Water & $7.72 \pm 0.47$ & $>300$ & $54.34 \pm 1.49$ & $8.23 \pm 0.34$ & $91.31 \pm 1.50$ \\
\hline \multirow{5}{*}{$N L$} & n-hexane & $90.70 \pm 8.17$ & $>300$ & $>100$ & 0 & $10.56 \pm 0.05$ \\
\hline & EA & $20.44 \pm 0.99$ & $>300$ & $100.62 \pm 1.13$ & $6.93 \pm 1.84$ & $52.99 \pm 0.36$ \\
\hline & Acetone & $21.87 \pm 1.64$ & $>300$ & $>100$ & 0 & $34.35 \pm 0.25$ \\
\hline & Ethanol & $15.58 \pm 0.48$ & $>300$ & $190.11 \pm 1.14$ & $7.12 \pm 0.34$ & $49.67 \pm 0.16$ \\
\hline & Water & $6.07 \pm 0.50$ & $>300$ & $125.82 \pm 1.44$ & $12.18 \pm 0.92$ & $111.34 \pm 1.64$ \\
\hline Positive control & -- & $\begin{array}{c}\text { (Gallic acid) } \\
0.86 \pm 0.02\end{array}$ & $\begin{array}{c}\text { (Catalase) } \\
1.51 \pm 0.01 \mathrm{U} / \mathrm{mL}\end{array}$ & $\begin{array}{c}\text { (Superoxidase) } \\
84.62 \pm 3.19 \mathrm{U} / \mathrm{mL}\end{array}$ & -- & -- \\
\hline
\end{tabular}

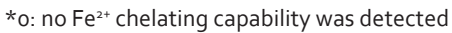

${ }^{*}$ Geographical source and aerial part-

M: Middle Taiwan; N: Northern Taiwan

S: Stem; B: Branch; L: Leaf

${ }^{*}$ : FRAP of each extract was showed as trolox equivalent $(\mu \mathrm{M})$ at the concentration of $100 \mu \mathrm{g}$ extract per milliliter 


\begin{tabular}{|c|c|c|c|c|}
\hline $\mathbf{R S R}^{*^{*}}$ & Extract solvent & $\begin{array}{c}\text { Total phenolic } \\
\mu \mathrm{g} \text { Gallic acid/ } \mathrm{mg}^{* \mathrm{~b}}\end{array}$ & $\begin{array}{l}\text { Total flavonoid } \\
\mu \mathrm{g} \text { Rutin/ } \mathrm{mg}^{\star \mathrm{b}}\end{array}$ & $\begin{array}{c}\text { Total flavanol } \\
\mu \mathrm{g} \text { epicatechin } / \mathrm{mg}^{\star b}\end{array}$ \\
\hline \multirow{5}{*}{ MS } & $n$-hexane & $81.98 \pm 2.07$ & $0.91 \pm 0.66$ & 0 \\
\hline & EA & $425.64 \pm 6.09$ & $18.15 \pm 1.47$ & $3.72 \pm 0.66$ \\
\hline & Acetone & $455.17 \pm 9.29$ & $30.94 \pm 2.66$ & $4.77 \pm 0.30$ \\
\hline & Ethanol & $238.98 \pm 5.64$ & $9.90 \pm 1.20$ & $1.90 \pm 0.05$ \\
\hline & Water & $207.11 \pm 2.94$ & $7.78 \pm 0.37$ & $10.92 \pm 0.05$ \\
\hline \multirow{5}{*}{$\mathrm{MB}$} & $n$-hexane & $9.37 \pm 3.57$ & $5.14 \pm 0.97$ & 0 \\
\hline & EA & $24.18 \pm 0.50$ & $10.22 \pm 1.50$ & $11.16 \pm 0.49$ \\
\hline & Acetone & $22.24 \pm 5.49$ & $8.52 \pm 0.84$ & $3.00 \pm 0.28$ \\
\hline & Ethanol & $52.79 \pm 0.82$ & $8.21 \pm 0.37$ & $11.29 \pm 0.49$ \\
\hline & Water & $88.56 \pm 2.07$ & $6.94 \pm 0.18$ & $17.89 \pm 0.20$ \\
\hline \multirow{5}{*}{$\mathrm{ML}$} & $n$-hexane & $8.63 \pm 1.54$ & $11.59 \pm 1.80$ & 0 \\
\hline & EA & $101.66 \pm 1.72$ & $73.24 \pm 5.04$ & $78.36 \pm 2.00$ \\
\hline & Acetone & $65.56 \pm 1.88$ & $34.01 \pm 1.80$ & $42.05 \pm 1.64$ \\
\hline & Ethanol & $140.66 \pm 2.30$ & $54.95 \pm 4.67$ & $60.38 \pm 2.05$ \\
\hline & Water & $328.19 \pm 9.92$ & $43.21 \pm 1.50$ & $86.50 \pm 1.35$ \\
\hline \multirow{5}{*}{ NS } & $n$-hexane & $18.12 \pm 8.53$ & $2.18 \pm 0.48$ & 0 \\
\hline & EA & $117.81 \pm 1.45$ & $5.46 \pm 0.18$ & $9.60 \pm 0.20$ \\
\hline & Acetone & $53.47 \pm 1.20$ & $5.67 \pm 0.32$ & $7.08 \pm 0.29$ \\
\hline & Ethanol & $165.45 \pm 1.90$ & $5.99 \pm 1.02$ & $14.54 \pm 1.04$ \\
\hline & Water & $178.14 \pm 3.10$ & $3.66 \pm 0.00$ & $23.96 \pm 0.19$ \\
\hline \multirow{5}{*}{ NB } & $n$-hexane & $15.75 \pm 0.33$ & $5.67 \pm 2.40$ & 0 \\
\hline & EA & $127.33 \pm 1.84$ & $12.65 \pm 1.28$ & $23.29 \pm 0.63$ \\
\hline & Acetone & $30.61 \pm 1.61$ & $10.00 \pm 1.57$ & $12.20 \pm 0.75$ \\
\hline & Ethanol & $52.46 \pm 0.50$ & $9.79 \pm 0.00$ & $11.88 \pm 0.68$ \\
\hline & Water & $141.32 \pm 8.46$ & $6.20 \pm 0.92$ & $11.59 \pm 0.00$ \\
\hline \multirow{5}{*}{ NL } & $n$-hexane & $18.89 \pm 0.24$ & $9.37 \pm 1.98$ & 0 \\
\hline & EA & $174.84 \pm 2.97$ & $51.78 \pm 5.32$ & $110.65 \pm 7.48$ \\
\hline & Acetone & $62.77 \pm 13.02$ & $29.89 \pm 4.12$ & $40.95 \pm 2.59$ \\
\hline & Ethanol & $102.52 \pm 0.68$ & $52.41 \pm 4.62$ & $43.29 \pm 0.61$ \\
\hline & Water & $123.64 \pm 5.09$ & $45.85 \pm 1.60$ & $64.00 \pm 0.00$ \\
\hline
\end{tabular}

$*_{0}$ : Total flavanol content cannot be detected

${ }^{*}$ Geographical source and aerial part-

M: Middle Taiwan; N: Northern Taiwan

S: Stem; B: Branch; L: Leaf

*b: all expressed in terms of standard equivalent ( $\mu \mathrm{g}$ of equivalent standard/ $\mathrm{mg}$ of extract) 


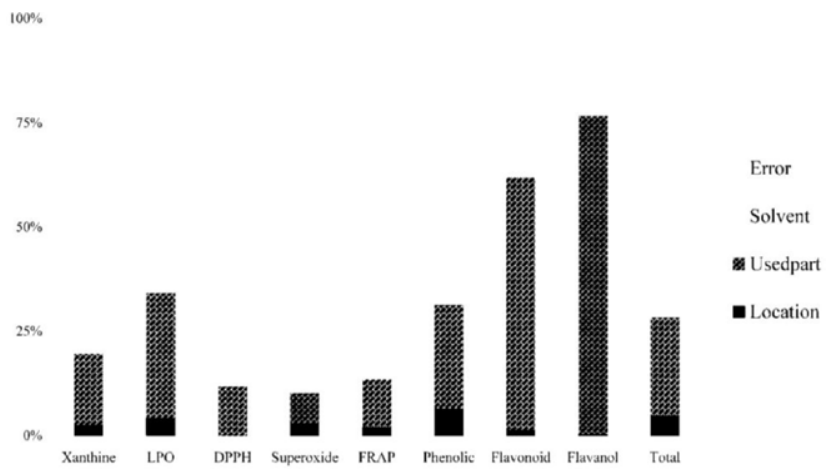

Figure 1: The influence factors on the XO and LPO inhibitory capabilities, antioxidant capabilities and phytochemical analysis.

*Error: error term, unable to be explained by these three factors in the linear relationship.

of the phytochemical constituents that dissolve in it. Variations in aerial parts are more influential in flavonoid and flavanol contents $(60.49 \%$ and $76.24 \%)$, where leaf extracts exhibit the maximum possibly due to its direct exposure to sunlight. Likewise, extracts from aerial part of RSR used in the study significantly affected LPO inhibition (stem and leaf) and total phenolic content (stem extracts higher) more than other factors. In summary, variation in extraction solvents $(27.37 \%)$ and aerial parts $(23.43 \%)$ mainly influenced the RSR activities, while variation in geographical source $(4.80 \%)$ has no significant impact on these activities suggesting that Middle and Northern Taiwan environment share the same primary ecological and climate factors influencing the active substance production of RSR including the annual average precipitation, temperature, sunshine duration, soil $\mathrm{pH}$, soil organic matter and rapidly available potassium in the soil that well described as being able to influence the production of metabolites. ${ }^{29,30}$

\section{CONCLUSION}

The leaf and stem of RSR are potential bio-source for developing anti-gout agent due to significant antioxidant activities leading to inhibitory effects against $\mathrm{XO}$ and LPO productions with all extracts exhibited liver damage protection. Results from Pearson correlation and general linear model (Univariate) suggest that polarities of different extraction solvents and aerial parts of RSR are mainly the influential factors to the observed activities. This study could give an insight about RSR as a potential candidate plant source to develop a natural anti-gout agent with liver damage protective ability that have yet to be conducted.

\section{Author Contributions}

Conceptualization, P.-W.T. and L.-L.Y.; methodology, formal analysis and data curation, P.-C.L., B.-C.W.,
M.-S.W. and L.-L.Y.; writing - original draft preparation, P.-W.T., A.-H.L., S.-J.S. and P.-C.L.; supervision, B.-C.W. and M.-S.W. All authors read and approved the final manuscript. P.-W.T. and P.-C.L. contributed equally to this work.

\section{ACKNOWLEDGEMENT}

The Alumni Foundation of Taipei Medical University, Taipei, Taiwan for the research grants; Department of Chinese Medicine and Pharmacy, Ministry of Health and Welfare (CCMP101-RD-007) for the partial research grant. A collaborating grant of Taipei Medical University and National Taipei University of Technology (USTP-NTUT-TMU-109-06) for the research grant. A collaborating grant of Taipei Medical University and National Taiwan University of Science and Technology (TMU-NTUST-103-10) for the research grant.

\section{CONFLICT OF INTEREST}

The authors declare that there is no conflict of interests regarding the publication of this article.

\section{ABBREVIATIONS}

RSR: Rhus semialata var. roxburghiana; XO: Xanthine oxidase; FRAP: Ferrous ion chelating capability; TPC: Total phenolic content; MS: Middle Taiwan RSR stem; MB: Middle Taiwan RSR branch; ML: Middle Taiwan RSR leaf; NS: Northern Taiwan stem; NB: Northern Taiwan RSR branch; NL: Northern Taiwan RSR leaf.

\section{REFERENCES}

1. Dave AJ, Kelly VM, Krishnan E. Pegloticase and the patient with treatmentfailure gout. Expert Review of Clinical Pharmacology 2012;5(5):501-8.

2. Berner JM, DerWesthuizen AJ. Inhibition of xanthine oxidase activity results in the inhibition of Russian wheat aphid-induced defense enzymes. Journal of Chemical Ecology. 2010;36(12):1375-80.

3. Zanotto-Filho A, Schröder R, Moreira JC. Xanthine oxidase-dependent ROS production mediates vitamin A pro-oxidant effects in cultured Sertoli cells. Free Radical Research. 2008;42(6):593-601.

4. Umamaheswari M, Asok KK, Somasundaram A, Sivashanmugam T, Subhadradevi V, Ravi TK. Xanthine oxidase inhibitory activity of some Indian medicinal plants. Journal of Ethnopharmacology. 2007;109(3):547-51.

5. Kramer HM, Curhan G. The association between gout and nephrolithiasis: the National Health and Nutrition Examination Survey III, 1988-1994. American Journal of Kidney Diseases. 2002;40(1):37-42.

6. Pacher P, Nivorozhkin A, Szabó $C$. Therapeutic effects of xanthine oxidase inhibitors: renaissance half a century after the discovery of allopurinol. Pharmacological Reviews. 2006;58(1):87-114.

7. Pereira S, Almeida J, Silva AO, Quintas M, Candeias O, Freitas F. Fatal liver necrosis due to allopurinol. Acta Médica Portuguesa. 1998;11(2):1141-4.

8. Lee MH, Graham GG, Williams KM, Day RO. A benefit-risk assessment of benzbromarone in the treatment of gout. Was its withdrawal from the market in the best interest of patients?. Drug Safety. 2008;31(8):643-65.

9. Agúndez JA, Lucena MI, Martínez C, Andrade RJ, Blanca M, Ayuso P, et al. Assessment of nonsteroidal anti-inflammatory drug-induced hepatotoxicity. Expert Opinion on Drug Metabolism and Toxicology. 2011;7(7):817-28. 
10. Crocenzi FA, Sisti A, Pellegrino JM, Roma MG. Role of bile salts in colchicineinduced hepatotoxicity: Implications for hepatocellular integrity and function. Toxicology. 1997;121(2):127-42.

11. Jomova K, Valko M. Advances in metal-induced oxidative stress and human disease. Toxicology. 2011;283(2-3):65-87.

12. Gutteridge JM. Biological origin of free radicals and mechanisms of antioxidant protection. Chemico-Biological Interactions. 1994;91(2-3):133-40.

13. Smith EU, Díaz-Torné C, Perez-Ruiz F, March LM. Epidemiology of gout: An update. Best Practice and Research Clinical Rheumatology. 2010;24(6):811-27.

14. Huang TC. 1993-96. Flora of Taiwan, $2^{\text {nd }}$ ed.; Committee of the Flora of Taiwan, $2^{\text {nd }}$ ed. Bot. Dept. NTU. Taipei. Taiwan. 2003;1-3:585.

15. Lin PC, Bi WF, Lin CH, Lee FP, Yang LL. Comparing different solvent extracts of Rhus semialata var. roxburghiana stem against ferrous ion-induced lipid peroxidation in mice liver mitochondria. Natural Product Communications. 2013;8(5):621-5.

16. Bose SK, Dewanjee S, Sen GA, Samanta KC, Kundu M, Mandal SC. In vivo evaluation of antidiarrhoeal activity of Rhus semialata fruit extract in rats. The African Journal of Traditional, Complementary and Alternative Medicines. 2007;5(1):97-102.

17. Kuo SC, Teng, CM, Lee LG, Chiu TH, Wu TS, Huang SC, et al. 6-Pentadecylsalicylic acid: an antithrombin component isolated from the stem of Rhus semialata var. roxburghii. Planta Medica. 1991;57(03):247-9.

18. Lin CN, Chen HL, Yen MH. Flavonoids with DNA strand-scission activity from Rhus javanica var. roxburghiana. Fitoterapia. 2008;79(1):32-6.

19. Ouyang MA, Wein YS, Zhang ZK, Kuo YH. Inhibitory activity against tobacco mosaic virus (TMV) replication of pinoresinol and syringaresinol lignans and their glycosides from the root of Rhus javanica var. roxburghiana. Journal of Agricultural and Food Chemistry. 2007;55(16):6460-5.

20. Devi HM, Singh NI. Traditional Medicinal Uses and Pharmacological Properties of Rhus chinensis Mill.: A Systematic Review. European Journal of Integrative Medicine. 2018:21:43-9.
21. Apaya KL, Chichioco-Hernandez CL. Xanthine oxidase inhibition of selected Philippine Medicinal Plants. Journal of Medicinal Plants Research. 2011;5(2):289-92.

22. Saeed N, Khan MR, Shabbir M. Antioxidant activity, total phenolic and total flavonoid contents of whole plant extracts Torilis leptophylla L. BMC Complementary and Alternative Medicine. 2012;12(1):221.

23. Gülçin I, Beydemir S. Phenolic Compounds as Antioxidants: Carbonic Anhydrse Isoenzymes Inhibitors. Mini-Reviews in Medicinal Chemistry. 2013;13(3):408-30.

24. Nu-Ri A, Ko JM, Cha HC. Comparison of Flavonoid Profiles between Leaves and Stems of Calystegia soldanella and Calystegia japonica. American Journal of Plant Sciences. 2012;3:1073-6.

25. Nile SH, Ko EY, Kim DH, Keum YS. Screening of ferulic acid related compounds as inhibitors of xanthine oxidase and cyclooxygenase- 2 with antiinflammatory activity. Revista Brasileira de Farmacognosia. 2016;26(1):50-5.

26. Tung YT, Chang ST. Inhibition of Xanthine Oxidase by Acacia confusa Extracts and Their Phytochemicals. Journal of Agricultural Food Chemistry. 2010;58(2):781-6.

27. Nessa F, Khan S. Evaluation of antioxidant and xanthine oxidase inhibitory activity of different solvent extracts of leaves of Citrullus colocynthis. Pharmacognosy Res. 2014;6(3):218-26.

28. Liu W, Liu J, Yin D, Zhao X. Influence of Ecological Factors on the Production of Active Substances in the Anti-Cancer Plant Sinopodophyllum hexandrum (Royle) T.S. Ying. PLoS One. 2015;10(4):e0122981.

29. Sampiao BL, Edrada-Ebel RA, DaCosta F. Effect of environment on secondary metabolic profile of Tithonia diversifolia: A model for environmental metabolomics of plants. Scientific Reports 2016;6:29265.

30. Szakiel A, Pączkowski C, Henry M. Influence of environmental abiotic factors on the content of saponins in plants. Phytochem. Rev 2010;10(4):471-91.
PICTORIAL ABSTRACT

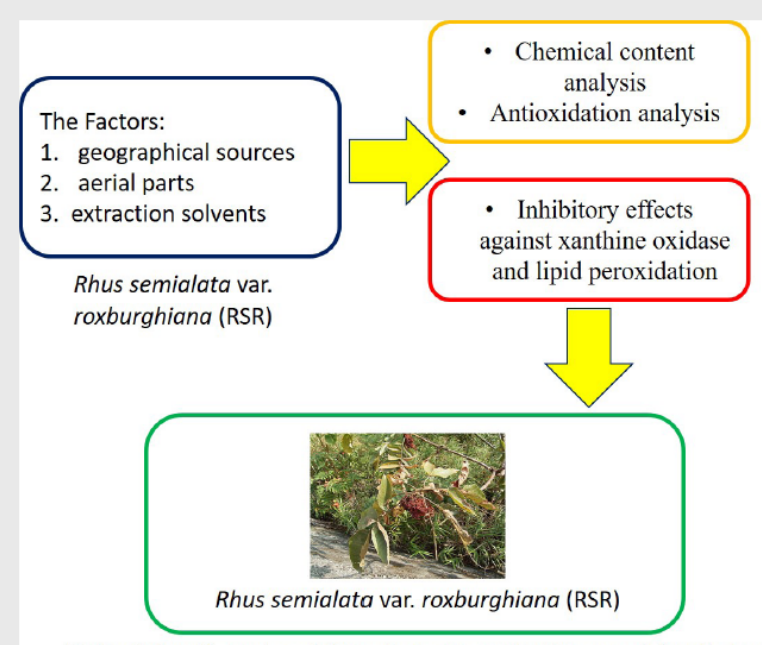

Potential anti-gout and liver damage protective agent development

\section{SUMMARY}

Gout, a disease characterized by recurrent inflammatory for urate deposit from overactive xanthine oxidase, is common among Taiwanese. Rhus semialata var. roxburghiana (RSR) grows wildly in Taiwan and used by aboriginal Taiwanese as traditional medicine for gout and hepatitis. The leaf and stem of RSR are potential bio-source for developing anti-gout agent due to significant antioxidant activities leading to inhibitory effects against $X O$ and LPO productions with all extracts exhibited liver damage protection. Results from Pearson correlation and general linear model (Univariate) suggest that polarities of different extraction solvents and aerial parts of RSR are mainly the influential factors to the observed activities. Overall, RSR could lead to a medicinal potential as a suitable candidate for the development of a natural anti-gout and liver damage protective agent that have yet to be conducted.

\section{About Authors}

Dr. Ming-Shun Wu is working as an Assistant Professor, School of Medicine, College of Medicine, Taipei Medical University, Taipei, Taiwan, also medical doctor at Division of Gastroenterology, Department of Internal Medicine, Wan Fang Hospital, Taipei, Taiwan. Author's area of interest is research activities in pharmacognosy, radiofrequency ablation of hepatocellular carcinoma and cellular stress response of colon cancer cells.

Cite this article: Tsai P, Lin P, Yang L, Shiue S, Liao A, Wang B, Wu M. Xanthine Oxidase and Lipid Peroxidation Inhibition of Taiwan Folkloric Medicine Factors Affecting Rhus semialata var. Roxburghiana Activities against Xanthine Oxidase and Ferrous Iron-induced Lipid Peroxidation on Mice Liver Mitochondria. Indian J of Pharmaceutical Education and Research. 2020;54(4):1062-71. 